\title{
WYKORZYSTANIE INTELIGENTNYCH BAZ DANYCH W BUDOWNICTWIE MOSTOWYM
}

\author{
Janusz Szelka ${ }^{1 凶}$, Zbigniew Wrona $^{2}$ \\ ${ }^{1}$ Wydział Budownictwa, Architektury i Inżynierii Środowiska, Uniwersytet Zielonogórski, Zielona Góra \\ ${ }^{2}$ Wydział Zarządzania, Wyższa Szkoła Zarządzania „Edukacja” we Wrocławiu, Wrocław
}

\begin{abstract}
STRESZCZENIE
Komputerowe wspomaganie problemów analityczno-decyzyjnych $\mathrm{w}$ budownictwie mostowym wymaga stosowania różnorodnych technologii informatycznych, takich jak bazy danych i systemy wspomagania decyzji, w tym systemy sztucznej inteligencji. Hybrydowe rozwiązania informatyczne, integrujące działania wskazanych technologii, są określane mianem inteligentnych baz danych. W opracowaniu przybliżono uwarunkowania zastosowania inteligentnych baz danych w obszarze budownictwa mostowego. Jako rozwiązanie o szczególnym znaczeniu wskazano dedukcyjne bazy danych, stanowiące połączenie tradycyjnych baz danych z systemami wnioskowania regułowego. Mogą one być z powodzeniem wykorzystywane np. w przedsięwzięciach doboru konstrukcji mostów tymczasowych czy monitorowania stanu obiektów mostowych, a uzupełnione o moduł sztucznej sieci neuronowej dodatkowo wspomagać realizację przedsięwzięć o charakterze predykcyjnym.
\end{abstract}

Słowa kluczowe: budownictwo mostowe, procesy analityczno-decyzyjne, bazy danych, systemy sztucznej inteligencji, inteligentne bazy danych, hybrydowe systemy informatyczne

\section{WSTĘP}

Informatyczne wspomaganie procesów analityczno-decyzyjnych w obszarze budownictwa mostowego wymaga wykorzystywania technologii i narzędzi o znacznym zróżnicowaniu. W przypadku części problemów stosowane są rozwiązania algorytmiczne (wykorzystujące odpowiednie modele matematyczne), inne wymagają podejścia heurystycznego (opartego na metodach i narzędziach sztucznej inteligencji). Dodatkowo można zauważyć, że złożoność i wieloetapowość problemów analityczno-decyzyjnych w tym obszarze sprawia, że niezbędne staje się wzajemne uzupełnianie wskazanych wyżej podejść i dopiero ich łączne zastosowanie umożliwia rozwiązanie sytuacji problemowej. Pociąga to za sobą konieczność wykorzystania niejednorodnych, hybrydowych rozwiązań informatycznych integrujących możliwości baz danych z systemami sztucznej inteligencji. Dedykowane rozwiązania informatyczne tego typu są obecnie z powodzeniem wykorzystywane w różnych obszarach zarządzania, a specyfika przedsięwzięć inżynieryjnych, ze szczególnym uwzględnieniem budownictwa mostowego, pozwala przypuszczać, że mogą być skutecznym narzędziem wspomagania procesów analityczno-decyzyjnych także w tym obszarze.

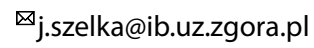




\section{METODY}

\section{Idea inteligentnych baz danych w obszarze wspomagania procesów analityczno-decyzyjnych}

Skuteczność informatycznego wspomagania procesów analityczno-decyzyjnych jest uwarunkowana, z jednej strony, dysponowaniem odpowiednimi zasobami informacyjnymi (danymi, wiedzą) zasilającymi te procesy, a z drugiej - informatycznymi narzędziami, zapewniającymi dostęp do tych zasobów i możliwość ich przetwarzania. Narzędziem wykorzystywanym powszechnie do gromadzenia i przechowywania danych (także w systemach wspomagających decyzje) są bazy danych. Z kolei dołączane do baz danych mechanizmy programowe, umożliwiające dostęp do danych (zaawansowane przeszukiwanie bazy danych) i zarządzanie nimi (łączenie danych, tworzenie agregatów danych itp.) określa się mianem systemu zarządzania bazą danych. Oba te współpracujące ze sobą komponenty tworzą system bazy danych (Beynon-Davies, 2004). O ile uznaje się, że systemy baz danych wraz z dołączonymi algorytmami przetwarzania danych są odpowiednimi narzędziami do wspomagania procesów informacyjnych i analitycznych, o tyle nie można ich uznać za skuteczne narzędzie wspomagania decyzji. Jedną z istotnych tego przyczyn jest własność tradycyjnych systemów baz danych, uwzględniająca tzw. założenie o zamkniętości świata. Oznacza ono, iż za prawdziwe uznaje się wyłącznie fakty, które zostały zapisane w bazie. Jeśli system zarządzania bazą danych nie może odnaleźć w bazie określonego faktu, to przyjmuje się, że nie jest on prawdziwy. Dodatkowo, tradycyjne systemy baz danych nie posiadają żadnych mechanizmów umożliwiających realizację procesów wnioskowania na podstawie posiadanych zasobów informacyjnych.

Z kolei można zauważyć, że zarówno systemy wspomagania decyzji dla problemów algorytmicznych, jak i systemy sztucznej inteligencji nie mają wbudowanych mechanizmów umożliwiających zarządzanie dużymi zbiorami danych ani zoptymalizowanego przeszukiwania takich zbiorów (Sroka i Wolny, 2009).

Wyzwaniom, polegającym na możliwości wspomagania zarówno procesów informacyjno-analitycznych, jak i decyzyjnych, wychodzą naprzeciw tzw. inteligentne bazy danych. Są to systemy hybrydowe przeznaczone do przechowywania i zaawansowanego przetwarzania danych zgromadzonych w tradycyjnej bazie danych, $\mathrm{z}$ wbudowanymi mechanizmami wnioskowania realizowanego na podstawie danych przechowywanych $w$ tej bazie.

Jedną z najczęściej wykorzystywanych kategorii inteligentnych baz danych, a jednocześnie potencjalnie użytecznych w obszarze budownictwa mostowego są dedukcyjne bazy danych. Są one tworzone poprzez dowiązanie do tradycyjnej (relacyjnej) bazy danych, zwanej bazą ekstensjonalną, bazy reguł wnioskowania, określanej mianem bazy intensjonalnej. W bazie ekstensjonalnej dane są przechowywane tradycyjnie, jako zbiory krotek gromadzonych w tabelach (relacjach). Obie bazy danych (ekstensjonalna i intensjonalna), wraz z systemem zarządzania tymi bazami danych, tworzą system inteligentnej (w tym przypadku dedukcyjnej) bazy danych (Ashish i Sushil, 2014). System zarządzania dedukcyjną bazą danych umożliwia wyprowadzanie z bazy jawnie przechowywanych tam danych oraz ich przetwarzanie (agregację, grupowanie), ale także pozwala na pozyskiwanie nowych faktów, niezapisanych w bazie danych bezpośrednio, ale ujawnionych w procesie przetwarzania reguł (rys. 1).

W bazie intensjonalnej krotki każdej relacji mogą być przedstawiane jako zbiory faktów. Na przykład krotki relacji Pracownik, zawierającej m.in. atrybuty: Id pracownika, Nazwisko, Stanowisko, Data zatrudnienia, byłyby reprezentowane przez zapisy typu: Pracownik (23, 'Nowak', 'monter', 2010-02-12). Z kolei w bazie intensjonalnej przechowywany jest zbiór reguł operujących na faktach.

Przykładowo, jeśli jedna z relacji bazy ekstensjonalnej służyłaby do przechowywania informacji o osobach: Osoba (Id_osoby, pleć), natomiast druga - do przechowywania danych identyfikujących rodzica danej osoby: Rodzic (Id_rodzica, Id_osoby), to do określenia zależności: wnuk-dziadek, można użyć następującej reguły: Wnuk (X,Y) IF Osoba (X,Płeć) AND Rodzic (Y,Z) AND Rodzic (Z,X) AND Płeć= 'm', przy czym zapis: Wnuk $(X, Y)$ należy odczytywać, jako: $X$ jest wnukiem $Y$ (tworzona jest nowa relacja o nazwie $W n u k$ i atrybutach: $I d$ wnuka,Id_dziadka). Takich informacji nie można odczytać bezpośrednio z ekstensjonalnej bazy danych, jednak użycie odpowiedniej reguły (zapisanej w bazie intensjonalnej) pozwala na wygenerowanie nowych faktów. 


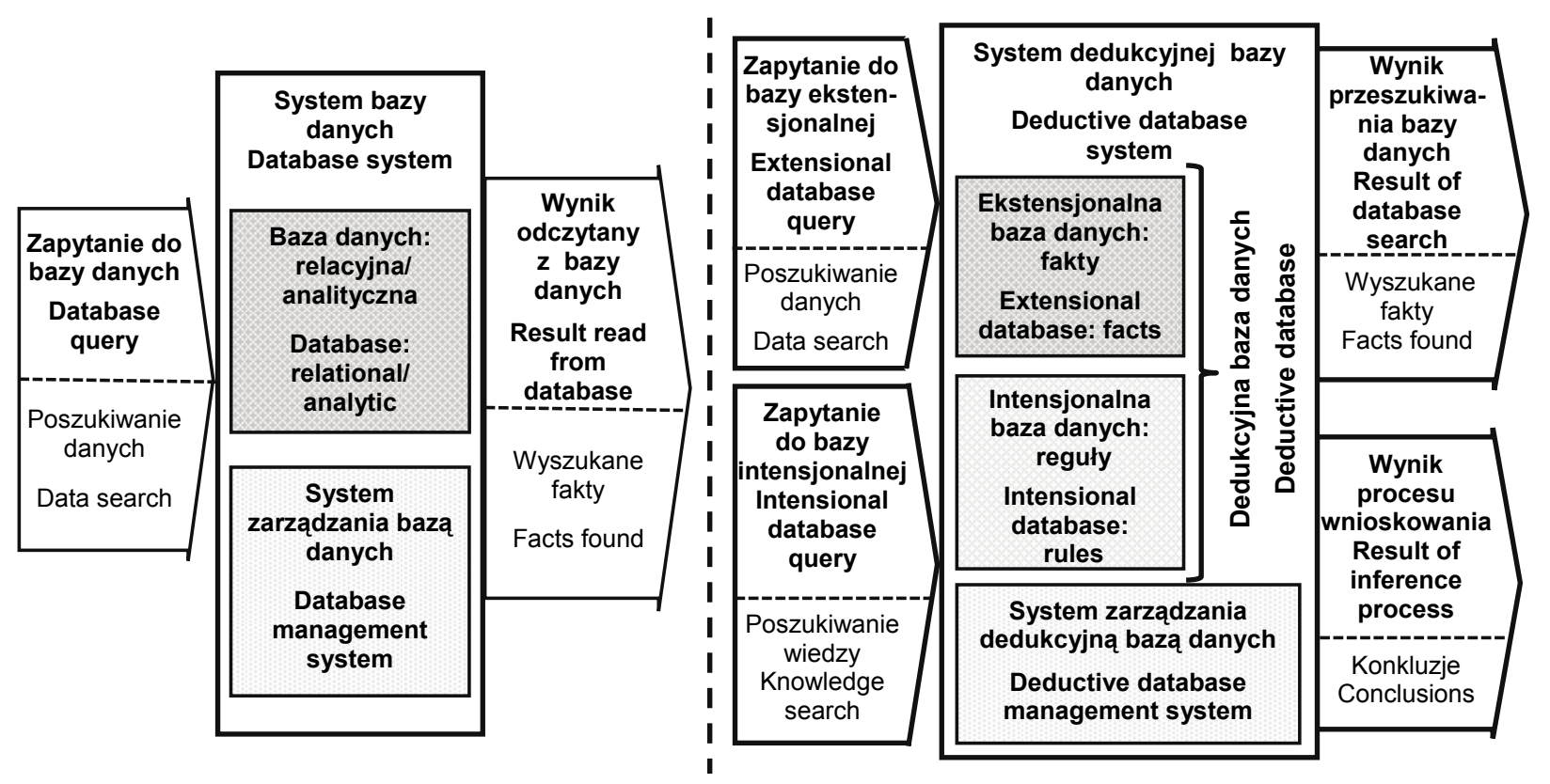

Rys. 1. Specyfika tradycyjnej i inteligentnej (dedukcyjnej) bazy danych

Fig. 1. The specificity of traditional and intelligent (deductive) database

Narzędziem programistycznym, umożliwiającym realizację systemów dedukcyjnych baz danych, jest język logiki, np. Prolog czy Datalog, wykorzystywany w połączeniu z tradycyjnym językiem tworzenia i obsługi baz danych $-S Q L$.

Warto zaznaczyć, że procesy wnioskowania $\mathrm{w}$ inteligentnych bazach danych nie muszą być realizowane wyłącznie na podstawie systemów regułowych. Można do tego celu wykorzystać także mechanizm sztucznej sieci neuronowej czy algorytmy genetyczne. Problemem w przypadku próby zapewnienia współdziałania bazy danych i sztucznych sieci neuronowych mogą być specyficzne wymagania sieci neuronowych co do sposobu reprezentacji danych wejściowych (dane wyłącznie w postaci numerycznej i dodatkowo - z określonego zakresu wartości) oraz brak możliwości dostępu do danych i ich przetwarzania z poziomu narzędzi programowych sztucznej sieci neuronowej. Przykładowo, jeśli dane wykorzystywane w ramach pakietu sztucznej sieci neuronowej Statistica Sieci Neuronowe są przechowywane w relacyjnej bazie danych, to należy wykorzystać dodatkowo środowisko ogólnego pakietu Statistica do ich przeskalowania, a ponadto inne pakiety (Statistica ETL, Statistica Query) w celu uzyskania dostępu do danych i możliwości ich przetwarzania (w tym - przeszukiwania). Podobne ograniczenia, co do postaci danych, występują w przypadku systemów wspomagania decyzji, wykorzystujących algorytmy genetyczne.

Oznacza to, że zastosowanie gotowych, zazwyczaj uniwersalnych rozwiązań informatycznych, pozwalających realizować zarówno złożone operacje na ustrukturyzowanych danych, jak i dokonywać procesu wnioskowania na podstawie zasobów bazy danych, wymusza stosowanie wielu złożonych aplikacji (modułów). Nie bez znaczenia są też znaczące koszty takich systemów związane z koniecznością stosowania zaawansowanych rozwiązań wielomodułowych.

Zasadne wydaje się zatem podjęcie próby wykorzystania dedykowanych systemów inteligentnych baz danych w przedsięwzięciach inżynieryjnych, a w szczególności w budownictwie mostowym jako rozwiązania bardziej ekonomicznego i mniej skomplikowanego technologicznie. 


\section{Możliwości wykorzystania inteligentnych baz danych w przedsięwzięciach budownictwa mostowego}

Analizując specyfikę przedsięwzięć z zakresu budownictwa mostowego, można uznać, że mamy w tym przypadku do czynienia z procesami niejednokrotnie niepowtarzalnymi, którym towarzyszy różnorodność materiałów, sprzętu i zespołów roboczych, a także znaczący wpływ warunków zewnętrznych (otoczenia) na rozwiązanie sytuacji problemowej.

Złożoność i niejednorodność problemu staje się jeszcze bardziej wyraźna w sytuacjach kryzysowych (np. klęska powodzi), dla których zwiększyć się może znacząco liczba ograniczeń (dostępność sprzętu, elementów konstrukcji, ograniczenia czasowe), wytyczających zbiór rozwiązań dopuszczalnych.

Przykładowo, jeśli sytuacja problemowa dotyczy planowania przepraw i wyboru rozwiązań konstrukcyjnych, to w jej opisie należałoby uwzględnić m.in. (Szelka, 1999):

- zestaw parametrów sprzętu inżynieryjnego ( $w$ tym sprzęt do budowy i utrzymania mostów, przeprawowy),

- przeszkody wodne (parametry rzek, obiektów hydrotechnicznych itp.),

- obiekty mostowe (identyfikacja mostu, typ i rodzaj konstrukcji mostu, typ i rodzaj konstrukcji podpór, liczba, typ i materiał przęseł, nośność mostu, stan techniczny itp.)

Wykorzystanie do tego celu dedukcyjnej bazy danych umożliwia sprawne przechowywanie wymaganych zbiorów danych przy użyciu typowych struktur relacyjnych. Fragment takiej struktury przedstawiono na rysunku 2

\begin{tabular}{|c|c|c|}
\hline $\begin{array}{c}\text { MOST_TYMCZAS } \\
\text { TEMPORARY_BRIDGE }\end{array}$ & $\begin{array}{l}\text { PARAMETRY_MONTAŻU } \\
\text { ASSEMBLY_PARAMETERS }\end{array}$ & $\begin{array}{l}\text { PRZESZKODA_WODNA } \\
\text { WATER_OBSTACLE }\end{array}$ \\
\hline $\begin{array}{l}\text { Id_mostu } \\
\text { Bridge_Id } \\
\text { Rodzaj_mostu } \\
\text { Bridge_Type } \\
\text { Nośność } \\
\text { Load_carrying_capacity } \\
\text { Długość } \\
\text { Length } \\
\text {... } \\
\text { Maks_rozpiętość } \\
\text { Maximum_span }\end{array}$ & $\begin{array}{l}\text { Nr_montażu } \\
\text { Assembly_No } \\
\text { Nr_przeszk_wodnej } \\
\text { Water_obstacle_No } \\
\text { Typ_podpory } \\
\text { Support_type } \\
\text { Technol_montażu } \\
\text { Assembly_technology } \\
\text { Liczba_dźwigów } \\
\text { Number_of_cranes } \\
\text {.... }\end{array}$ & $\begin{array}{l}\text { Nr_przeszkody } \\
\text { Water_obstacle_no } \\
\text { Szerokość_przeszkody } \\
\text { Obstacle_width } \\
\text { Głębokość_przeszkody } \\
\text { Obstacle_depth } \\
\text { Charakter_dna } \\
\text { Bottom_type } \\
\text {... }\end{array}$ \\
\hline
\end{tabular}

Rys. 2. Uproszczona struktura relacyjnej bazy danych, wykorzystywanej w obszarze budownictwa mostowego

Fig. 2. A fragment of relational database structure used in bridge construction

Wybrane dane gromadzone w relacjach PRZESZKODA_WODNA oraz PARAMETRY_MONTAŻU przedstawiono w tabeli 1. 


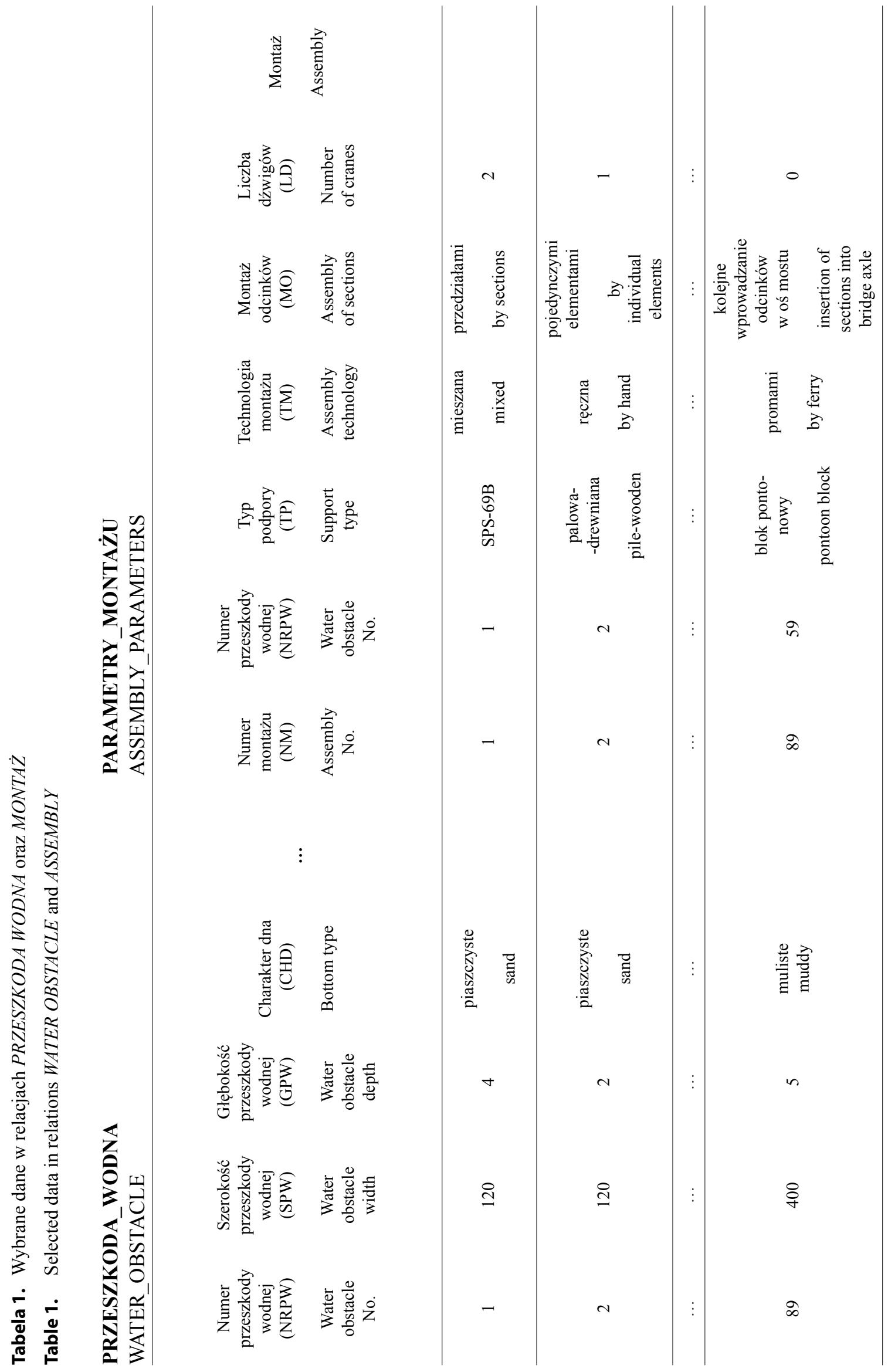


Wskazane struktury danych (relacje) będą reprezentowane w bazie ekstensjonalnej przez zapisy:

Przeszkoda_Wodna (NRPW,SPW,GPW,CHD)

Parametry_Montażu (NM,NRPW,TP,TM,MO,LD)

Przykładowe zapisy faktów dla powyższych struktur mogą przyjmować postać:

Przeszkoda_Wodna (2,120,2, 'piaszczyste')

Parametry_Montażu (2,2, 'palowo-drewniana','ręczna', 'pojedynczymi elementami', 1)

Znaczna część wymienionych problemów, takich jak np. dostęp do parametrów przeszkód wodnych czy zapytania o przedsięwzięcia montażu, spełniające określone warunki, może być rozstrzygnięta w wyniku bezpośredniego zapytania do ekstensjonalnej bazy danych. Reguły zapisane w bazie intensjonalnej mogą mieć postać zapytań o fakty znajdujące się bezpośrednio w bazie danych, np. pokazujące zastosowane typy podpór i technologie montażu w przypadku przedsięwzięć realizowanych dla przeszkód wodnych o szerokości ponad $200 \mathrm{~m}$ i piaszczystym charakterze dna (symbolem ,", oznaczono parametry nieistotne z punktu widzenia tworzonego zapytania):

Wynik (TP,TM) IF Przeszkoda_Wodna (_SPW, , CHD) AND SPW>200 AND CHD='piaszczyste' AND Parametry_Montażu(_,TP, TM,_, )

Rezultat zapytania zostanie zapisany w ekstensjonalnej bazie danych jako zbiór faktów należących do relacji o nazwie Wynik. W bazie intensjonalnej mogą być przechowywane także reguły stanowiące zapytania o fakty, które nie wynikają wprost z zawartości bazy danych, np.:

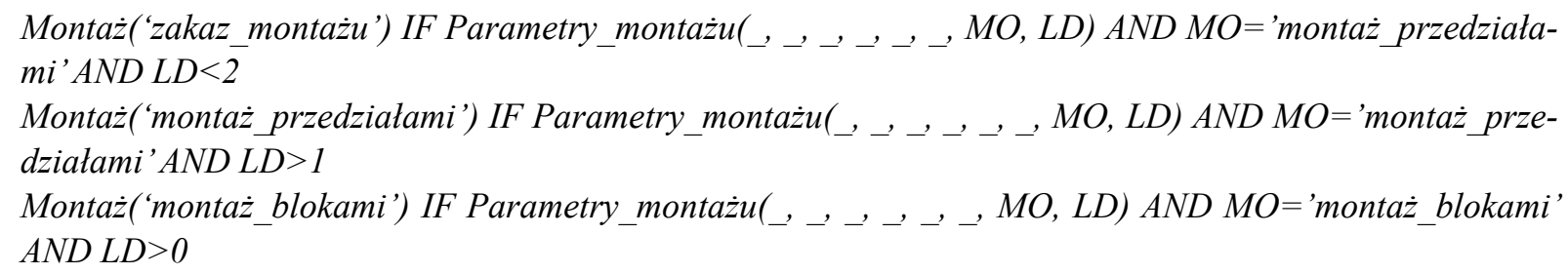

Tego typu zbiór reguł może być wykorzystany do realizacji procesu wnioskowania, dotyczącego wyboru sposobu montażu przęseł dla przedsięwzięcia montażu, dla którego znane są: sposób montażu odcinków przęseł oraz liczba dźwigów, którą dysponuje wykonawca.

Dedukcyjne bazy danych mogą być wykorzystywane do wspomagania problemów związanych z doborem rozwiązań konstrukcyjnych, zadań dotyczących klasyfikacji, a także monitorowania stanu obiektu mostowego (poprzez mechanizmy podobne do tych, które są charakterystyczne dla aktywnych baz danych). Nie są jednak odpowiednim narzędziem do rozwiązywania problemów o charakterze predykcyjnym (prognozowanie stanu obiektu mostowego lub jego elementów) czy zadań wymagających aproksymowania funkcji, opisującej np. zużycie materiału, zwłaszcza w sytuacjach niekompletności danych wejściowych. W takich przypadkach racjonalne rozwiązanie mogłyby stanowić systemy hybrydowe, skonstruowane na podstawie relacyjnych bądź strumieniowych baz danych, powiązanych z mechanizmem sztucznych sieci neuronowych. Moduł obsługi bazy danych (relacyjna baza danych i system zarządzania bazą danych) pełni w tym przypadku analogiczną rolę jak ekstensjonalna baza danych wraz z systemem zarządzania nią w dedukcyjnej bazie danych, natomiast moduł sieci neuronowej, pobierający dane z bazy danych, po ich przeskalowaniu do wymagań sieci mógłby być wykorzystywany do prognozowania czy aproksymacji funkcji. 


\section{PODSUMOWANIE}

Komputerowe wspomaganie złożonych i niejednorodnych przedsięwzięć analityczno-decyzyjnych w obszarze budownictwa mostowego wymaga stosowania różnorodnych technologii informatycznych. Duże znaczenie odgrywają tu zwłaszcza systemy baz danych, umożliwiające sprawne przeszukiwanie i przetwarzanie zasobów informacyjnych. Muszą być one jednak uzupełniane o rozwiązania informatyczne umożliwiające realizację procesu wnioskowania, głównie wykorzystujące mechanizmy sztucznej inteligencji. Możliwości współpracy autonomicznych systemów baz danych z systemami sztucznej inteligencji należy jednak uznać za ograniczone. Połączenie technologii baz danych z systemami realizującymi wnioskowanie heurystyczne pozwala na tworzenie tzw. inteligentnych baz danych.

Rozwiązaniem o szczególnym znaczeniu w zakresie wspomagania procesów analityczno-decyzyjnych w budownictwie mostowym wydają się dedukcyjne bazy danych, stanowiące połączenie tradycyjnych baz z systemami wnioskowania regułowego. To zintegrowane narzędzie hybrydowe można wykorzystywać np. w przedsięwzięciach doboru konstrukcji mostów tymczasowych, zadaniach klasyfikacji uszkodzeń czy monitorowania stanu obiektów mostowych. Jednak do wspomagania niektórych kategorii problemów, jak np. predykcji stanu obiektu czy aproksymowania funkcji zużycia elementów konstrukcji mostu, najodpowiedniejszym narzędziem wydają się sztuczne sieci neuronowe. Wydaje się zatem, że racjonalnym rozwiązaniem w zakresie inteligentnej bazy danych (choć jednocześnie bardziej rozbudowanym i trudniejszym implementacyjnie) w rozpatrywanym obszarze byłaby dedukcyjna baza danych $\mathrm{z}$ dodatkowym modułem sztucznej sieci neuronowej. $Z$ kolei to rozwiązanie można rozbudowywać o kolejne moduły sztucznej inteligencji, np. umożliwiające realizację procesów optymalizacyjnych, dla których właściwym narzędziem informatycznym są aplikacje oparte na algorytmach genetycznych.

\section{PIŚMIENNICTWO}

Ashish, K. i Sushil, M. (2014). An Introduction To Deductive Database And Its Query Evalution. International Journal of Advanced Computer Technology, 3 (3), 33-36.

Beynon-Davies, P. (2004). Systemy baz danych. Warszawa: Wydawnictwo Naukowo-Techniczne.

Sroka, H. i Wolny, W. (2009). Inteligentne systemy wspomagania decyzji. Katowice: Wydawnictwo Akademii Ekonomicznej w Katowicach.

Szelka, J. (1999). Obiektowy zapis wiedzy w systemach eksperckich wspomagających budowę mostów wojskowych. Warszawa: Wydawnictwo WAT.

\section{THE EMPLOYMENT OF INTELLIGENT DATABASES IN BRIDGE CONSTRUCTION}

\section{SUMMARY}

Computer aiding for analytical and decision problems in bridge construction requires the use of a variety of information technologies such as databases and decision support systems, including artificial intelligence systems. Hybrid IT solutions, which integrate the operations of the technologies mentioned above, are referred to as intelligent databases. The paper outlines the conditions for the use of intelligent databases in bridge construction. It demonstrates that deductive databases, which combine traditional databases with rule-based inference systems, are a solution of special significance. They can be successfully used, for instance, for the selection of temporary bridges or the monitoring of the condition of bridge facilities. When supplemented with an artificial neural network module, they can additionally support the realization of projects of predictive nature.

Key words: bridge construction, analytical and decision-making processes, databases, artificial intelligence systems, intelligent databases, hybrid IT systems 